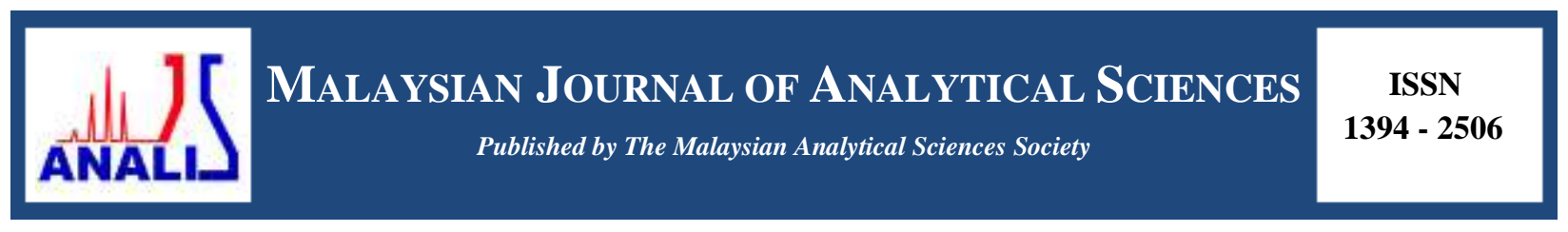

\title{
GAMMA RADIATION-INDUCED GRAFTING OF ACETIC ACID ONTO EXPANDED POLY(TETRAFLUOROETHYLENE) MEMBRANES FOR BIOMATERIAL APPLICATIONS
}

\author{
(Pencantuman Teraruh Sinaran Gama Asid Asetik ke atas Regangan Membran \\ Poli(tetrafluoraetilena) bagi Aplikasi Biobahan) \\ Zaitizila Ismail, Norsyahidah Mohd Hidzir*, Nur Ain Mohd Radzali, Irman Abdul Rahman \\ School of Applied Physics, Faculty of Science and Technology, \\ Universiti Kebangsaan Malaysia, 43600 UKM Bangi, Selangor, Malaysia \\ *Corresponding author: syahidah@ukm.edu.my
}

Received: 23 November 2016; Accepted: 10 April 2017

\begin{abstract}
Expanded poly(tetrafluoroethylene) (ePTFE) is used for many applications including in medical applications, such as for facial implants or as artificial vascular valves. However, due to its natural hydrophobic properties, it has limited efficacy in some applications. To be used as a facial implant, ePTFE must be biocompatible to the surrounding living tissues. Therefore, the modification of the ePTFE surface through a radiation-induced grafting technique was introduced in this study. Acetic acid (AA) was used as a monomer grafted onto ePTFE due to its hydrophilic properties. Monomer concentrations and radiation doses were observed to play an important role in the grafting outcomes. A dose of $15 \mathrm{kGy}$ of $\gamma$-ray and $20 \%$ of AA concentration was observed to be an optimum grafting parameter in this study with the maximum grafting yield of $14 \pm 4 \%$. The result also showed a decrease of surface hydrophobicity for grafted ePTFE with the water contact angle decreased $18^{\circ}$ (from $117^{\circ}$ to $99^{\circ}$ ). No extra band was observed in attenuated total reflectance infrared (ATR-FTIR) spectroscopy for grafted ePTFE, which indicated that grafting might occur only on the very top layer of ePTFE. Analysis from field emission scanning electron microscopy coupled with energy dispersive X-ray (FESEM/EDX) revealed a successful grafting as the oxygen peak can be seen on the treated sample.
\end{abstract}

Keywords: radiation-induced grafting, grafting, expanded poly(tetrafluoroethylene), acetic acid

\footnotetext{
Abstrak

Poli(tetrafluoroetilena) regangan (ePTFE) digunakan dalam pelbagai aplikasi termasuklah dalam aplikasi perubatan, contohnya sebagai implan pada wajah atau sebagai vaskular injap tiruan. Walau bagaimanapun sifat semulajadi ePTFE yang hidrofobik menyebabkan keberkesanannya adalah terhad dalam beberapa aplikasi. ePTFE mestilah mempunyai tahap integrasi biologi yang optimum untuk digunakan sebagai implan wajah. Justeru, pengubahsuaian permukaan ePTFE meggunakan teknik pengkopolimeran menggunakan sinar gama diperkenalkan dalam kajian ini. Asetik asid digunakan sebagai monomer untuk tujuan percantuman dengan ePTFE disebabkan sifatnya yang hidrofilik. Dos sinaran dan kepekatan monomer yang digunakan menunjukkan peranan yang penting dalam peratusan hasil pencantuman. Parameter optimum telah dikenalpasti dalam kajian ini (iaitu dos sinaran $15 \mathrm{kGy}$ dan kepekatan AA sebanyak 20\%) dengan menghasilkan nilai cantuman tertinggi sebanyak $14 \pm 4 \%$. Hasil juga menunjukkan sifat hidrofobik permukaan ePTFE berkurang sebanyak $18^{\circ}$ dengan menganalisis sudut permukaan air (iaitu daripada $117^{\circ}$ menjadi $99^{\circ}$ ). Hasil keputusan analisis (ATR-FTIR) tidak menunjukkan sebarang perubahan spektrum berkemungkinan disebabkan pencantuman berlaku pada permukaan ePTFE sahaja. Manakala hasil keputusan daripada analisis (FESEM/EDX) menunjukkan ada pertambahan puncak oksigen di dalam analisis sampel yang telah disinar dan dicantum dengan AA, justeru menunjukkan percantuman berjaya berlaku.
} 


\section{Zaitizila et al: GAMMA RADIATION-INDUCED GRAFTING OF ACETIC ACID ONTO EXPANDED POLY(TETRAFLUOROETHYLENE) MEMBRANES FOR BIOMATERIAL APPLICATIONS}

Kata kunci : sinaran mengaruh pencantuman, pencantuman, poli(tetrafluoroetilena) rengangan, asetik asid

\section{Introduction}

Poly(tetrafluoroethylene) (PTFE) is widely used in many different industries, such as petrochemical and chemical, electrical, semiconductor, food and beverage, pharmaceutical, and medical industries. The variety of applications of these polymers is possible because PTFE possesses high thermal and chemical stability [1]. This is due to the helical structure of the polymer chain caused by the relatively larger size of fluorine atoms compared to carbon atoms. The PTFE is also naturally hydrophobic, non-reactive, non-polar, and has low surface tension.

Expanded poly(tetrafluoroethylene) (ePTFE) is relatively similar to PTFE, but the difference is in morphology and surface conditions. The ePTFE is proven to be more favourable than the non-expanded version because it has a more porous membrane, excellent dielectric properties, and a drastic reduction in creep, which is a weakness of standard PTFE [2]. In addition, ePTFE is used to make lightweight, waterproof, and breathable fabrics, microporous membranes, medical tubes and implants, microwave carriers, industrial sealants, and high-tensile fabrics and cords. Moreover, ePTFE has been reported to perform well as a vascular graft, where its porous property is sufficient to promote endothelial healing with cellular and capillary growth. These properties also make ePTFE one of the best resorbable materials to be used as a tissue implant in the face [3]. However, high hydrophobicity of ePTFE limits the use of this polymer, especially as biomaterial where it is required to make a good integration with the surrounding living tissues. Therefore, its surface properties need to be altered so that it will match the uses of its intended applications [4].

Surface modification of a polymer via grafting techniques can be used to change the properties of any polymer surface so that the desired characteristics can be achieved. Grafting can be described as the covalent attachment process. Currently, there are various grafting techniques available to modify a polymer surface, including chemical treatment [5], photografting [6], radiation [7, 8], and plasma techniques [9]. Radiation-induced graft copolymerisation is one of the grafting techniques that has been well established for almost half a century [10]. These techniques can alter the initial surface of polymeric materials by introducing new functional groups on the backbone of the carbon chain. Many studies have been conducted using the radiation-induced grafting technique in which various monomers have been successfully introduced onto ePTFE, such as acrylic acid [8], itaconic acid [7], and methoxyacrylate phosphate [11]. In the current study, acetic acid (AA) was chosen as the grafting monomer to introduce the carboxylic acid group onto the surface of the ePTFE. The effects of the concentration of the monomer and radiation dose on the grafting outcomes were investigated using various characterisation techniques, including attenuated total reflectance infrared (ATR-FTIR) spectroscopy, field emission scanning electron microscopy (FESEM) coupled with energy dispersive X-ray (EDX) and water contact angle measurements.

\section{Materials}

\section{Materials and Methods}

The ePTFE membranes $\left(0.022 \mathrm{~mm}\right.$ thick, dimension of $\left.15 \times 10 \mathrm{~mm}^{2}\right)$ were obtained from Pall Corporation under the trade name Zefluor ${ }^{\mathrm{TM}}(0.5 \mu \mathrm{m})$. The membranes were pre-treated with methanol overnight $40{ }^{\circ} \mathrm{C}$ to remove contaminants before being dried in the oven to a constant weight. Methanol was obtained from MERCK; AA was purchased from Systerm, and ammonium iron (II) sulphate hexahydrate (Mohr's salt) was obtained from Honeywell Riedel-de Haen.

\section{Grafting procedure}

For the AA grafting experiment, $4 \mathrm{~mL}$ of deionised water and $40 \mathrm{mg}$ of Mohr's salt were added to different AA concentrations $(2,10$, and $20 \mathrm{w} / \mathrm{v} \%)$ to form the monomer solution. The ePTFE samples (weight $2-3 \mathrm{mg}$ ) were placed in the monomer solution. All test tubes were covered using parafilm, and the solution was degassed with nitrogen for 15 minutes to remove the dissolved oxygen from the solution. The test tubes were sealed with caps and parafilm. Samples were then irradiated at ambient temperature using $\gamma$-rays (gamma cell 220 excel) with doses of 2 $\mathrm{kGy}, 5 \mathrm{kGy}, 10 \mathrm{kGy}$, and $15 \mathrm{kGy}$ at a dose rate of $1.8 \mathrm{kGy} / \mathrm{h}$. After the irradiation process, the samples were washed with hot methanol at $40{ }^{\circ} \mathrm{C}$ for 1 hour to remove any occluded homopolymer or unreacted monomer. Then, the grafted sample was further washed with deionised water three times for 1 hour each and finally left in the water 
overnight. The grafted samples i.e., ePTFE-grafted polyacetic acid (ePTFE-g-PAA) were dried in the desiccator jar over 3 days until a constant weight was achieved. The sample grafted with AA was named $\mathrm{AA}(m) d$ where $m$ refers to concentration of the monomer and $d$ to the dose (e.g., samples grafted in $2 \%$ AA at dose of $15 \mathrm{kGy}$ were named $\mathrm{AA}(2) 15)$.

\section{Characterisation}

The graft yield was determined from the initial and final weight of samples obtained using the electronic balance (Scaltex SBA31). The graft yield was measured using the formula:

$$
\text { Graft yield }(\%)=\left[\frac{(W f-W i)}{W i}\right] \times 100 \%,
$$

where $\mathrm{W}_{\mathrm{i}}$ is the initial weight of the sample and $\mathrm{W}_{\mathrm{f}}$ is the weight of grafted sample. The average and standard deviation are reported on triplicate samples.

Water uptake was obtained by immersing the ePTFE and grafted ePTFE in water overnight. The samples were removed from the water, and filter paper was used to remove any surface water before the sample weight was determined. The equilibrium water uptake was calculated using the formula:

$$
\text { Water uptake }(\%)=\left[\frac{(\text { Ws }- \text { Wd })}{\text { WPAA }}\right] \times 100 \% \text {, }
$$

where $\mathrm{W}_{\mathrm{s}}$ is the weight of the swollen sample, $\mathrm{W}_{\mathrm{d}}$ is the weight of dry sample, and $\mathrm{W}_{\text {PAA }}$ is the mass of PAA on the grafted membrane. The average and standard deviation are reported on triplicate samples.

The contact angle measurement was performed via a custom-built setup, as previously described [8], using an automated angle goniometer machine (Rama Hart). Samples were placed on a Teflon stage, and $5 \mu \mathrm{L}$ drops of deionised water were delivered onto the sample surface via a $50 \mu \mathrm{L}$ glass flat-tip syringe. The measurements were taken at least five times for each sample, and the average measurement was taken.

Attenuated total reflectance infrared (ATR-FTIR) spectroscopy (model Perkin Elmer Spectrum BX) with a resolution of $8 \mathrm{~cm}^{-1}$ and wavenumber range $400 \mathrm{~cm}^{-1}-4000 \mathrm{~cm}^{-1}$ were used in this analysis. A FESEM/EDX analysis (Merlin compact model) was performed on the sample. All samples were coated with platinum for 5 min until a $15 \mathrm{~nm}$ thick layer had formed to make the material conductive. The FESEM/EDX analysis was performed under the standard high vacuum mode with the voltage at $3 \mathrm{kV}$. The morphology of each sample was obtained with various magnifications: $1.00 \mathrm{~K} \mathrm{x}, 3.00 \mathrm{~K} \mathrm{x}, 5.00 \mathrm{~K} \mathrm{x}$, and $10.00 \mathrm{~K} \mathrm{x}$.

\section{Effects of grafting parameters on ePTFE and grafted ePTFeussion \\ Results and Discussion}

The increased graft yield after radiation-induced grafting of AA onto ePTFE possibly indicated the success of the grafting process. Table 1 shows the increased graft yield of grafted samples with increased radiation doses and monomer concentrations. At similar concentrations of AA (i.e., $20 \mathrm{w} / \mathrm{v} \%$ ), samples irradiated at higher doses (sample AA(20)15 and AA(20)10) showed higher grafting outcomes at approximately 14\% compared to samples that have been irradiated at lower doses (sample AA(20)2) with a graft yield at approximately only 5\%. The increased graft yield with higher doses, possibly due to the number of radicals produced at higher doses of radiation, initiated the primary radical of the polymer and monomer unit [12]. Thus, the increased radicals that could take part in the grafting reaction caused the degree of grafting to be increased [13].

In addition, the graft yield was observed to be increased with the increased AA concentrations at 5, 10, and $15 \mathrm{kGy}$. The percentage of grafting increased approximately $2-5 \%$ when AA concentrations increased from 2 to $20 \mathrm{w} / \mathrm{v} \%$ for 5, 10, and $15 \mathrm{kGy}$. The increased graft yield with monomer concentrations was possibly because the grafting proceeds by a diffusion controlled mechanism, which takes place at the surface of the sample and gradually proceeds further by progressive diffusion of the monomer through the medium of the swollen grafted layer. It is also 
assumed that the grafting begins at the polymer surface, then gradually proceeds inward as the grafting zone is swollen by the monomer solution $[10,14]$.

However, the percentage of grafting in these experiments was lower compared to the study conducted by Hidzir et al. [8], which used acrylic acid as the monomer that showed the highest grafting yield of $36 \pm 3 \%$ at $20 \%$ monomer concentration with a $15 \mathrm{kGy}$ dose. The differences of the percentage of grafting obtained from the previous study compared to the current study were possibly due to the characteristic of the monomer. As AA consists of two carbons that could covalently attach to ePTFE, whereas an acrylic acid has three carbons (Figure 1), only a few carbons of AA can form a bond to the carbon chain of ePTFE, which resulted in lower grafting yield from this monomer. In addition, acrylic acid has an unsaturated bond (i.e., double bond) that could easily break upon irradiation; therefore, more grafting onto ePTFE could easily be obtained with the used of acrylic acid as a monomer.

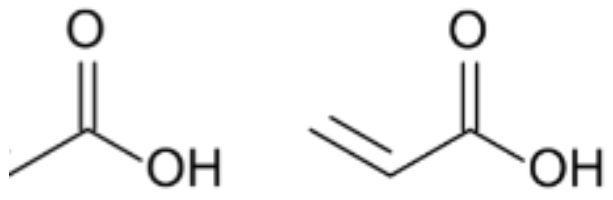

Figure 1. Chemical structure of acetic acid (left) and acrylic acid (right)

Table 1. Characterisation of ePTFE grafted membranes

\begin{tabular}{lccccc}
\hline Sample & $\begin{array}{c}\text { Dose } \\
(\mathbf{k G y})\end{array}$ & $\begin{array}{c}\text { Monomer Concentration } \\
(\mathbf{w} / \mathbf{\%})\end{array}$ & $\begin{array}{c}\text { Graft Yield } \\
(\boldsymbol{\%})\end{array}$ & $\begin{array}{c}\text { Water Uptake } \\
(\boldsymbol{\%})\end{array}$ & $\begin{array}{c}\text { Contact Angle } \\
\boldsymbol{\theta}\left(\mathbf{(}^{\circ}\right)\end{array}$ \\
\hline ePTFE & 0 & 0 & 0 & 0 & 117 \\
$\mathrm{AA}(2) 2$ & 2 & 2 & $7 \pm 4$ & $233 \pm 58$ & na \\
$\mathrm{AA}(10) 2$ & 2 & 10 & $7 \pm 3$ & $250 \pm 87$ & na \\
$\mathrm{AA}(20) 2$ & 2 & 20 & $5 \pm 0$ & $533 \pm 208$ & na \\
$\mathrm{AA}(2) 5$ & 5 & 2 & $9 \pm 3$ & $317 \pm 161$ & na \\
$\mathrm{AA}(10) 5$ & 5 & 10 & $7 \pm 4$ & $600 \pm 265$ & na \\
$\mathrm{AA}(20) 5$ & 5 & 20 & $11 \pm 5$ & $444 \pm 236$ & na \\
$\mathrm{AA}(2) 10$ & 10 & 2 & $9 \pm 4$ & $250 \pm 132$ & 111 \\
$\mathrm{AA}(10) 10$ & 10 & 10 & $10 \pm 2$ & $333 \pm 29$ & 106 \\
$\mathrm{AA}(20) 10$ & 10 & 20 & $14 \pm 4$ & $372 \pm 95$ & 104 \\
$\mathrm{AA}(2) 15$ & 15 & 2 & $8 \pm 5$ & $683 \pm 126$ & na \\
AA(10)15 & 15 & 10 & $10 \pm 4$ & $733 \pm 333$ & 103 \\
AA(20)15 & 15 & 20 & $12 \pm 2$ & $967 \pm 76$ & 99 \\
\hline
\end{tabular}

*na - data not available

\section{Water uptake and water contact angle analysis of ePTFE and grafted ePTFE}

The percentage of water uptake increased with the increased monomer concentrations and doses. At the highest grafting parameter (i.e., highest dose and monomer concentration used in this study), sample AA(20)15 showed the highest water uptake with $967 \pm 76 \%$ compared to untreated ePTFE ( $0 \%$ water uptake) and samples that have been grafted at lower doses and monomer concentrations (e.g., sample AA(2)10 with water uptake of $250 \pm 132 \%$ ). This result was in line with the measurement obtained from water contact angle analysis where high hydrophobicity of 
ePTFE $\left(117^{\circ}\right)$ decreased significantly by $\sim 18^{\circ}$ to became less hydrophobic for grafted samples (sample AA(20) 15 with water contact angle of $99^{\circ}$ ). The increased water uptake and decreased water contact angle showed that the carboxylic functional group from the AA has successfully grafted onto ePTFE. At higher AA concentrations, more grafting of this carboxylic acid group occurred, thus resulting in a higher percentage of water uptake. The results in this study were similar to the previous studies reported by Wu et al. [4] and Hidzir et al. [8]. According to Wu et al. [4], the ePTFE surface angle can be reduced from $125^{\circ}$ to $72^{\circ}$ using the AA plasma deposition procedure. In addition, Hidzir et al. [8] reported that the surface water contact angle obtained is $92^{\circ}$ for the grafted sample (ePTFE that has been irradiated at a dose of $10 \mathrm{kGy}$ and $40 \%$ concentration of acrylic acid).

\section{Chemical characterisation of ePTFE and grafted ePTFE}

Figure 2(a) shows an FTIR spectra for untreated ePTFE, which displays the $\sigma$ band at $1208 \mathrm{~cm}^{-1}$ and $1154 \mathrm{~cm}^{-1}$, which were assigned as the $\mathrm{CF}_{2}$ stretching mode, and the band at $637 \mathrm{~cm}^{-1}$ and $555 \mathrm{~cm}^{-1}$, which were assigned to the $\mathrm{CF}_{2}$ wagging mode and $\mathrm{CF}_{2}$ deformation mode [8]. No additional band was observed on the sample that has been grafted with AA (e.g., sample AA(20)15) (Figure 2(b)) compared to the untreated sample. In the study by Hidzir et al. [8], the carbonyl band of the carboxylic acid group can be seen at $1716 \mathrm{~cm}^{-1}$, and the hydroxyl groups are present on the band $3000-3600 \mathrm{~cm}^{-1}$. The undetected presence of the carbonyl group and hydroxyl groups on the spectrum of the current study (sample AA(20)15) is possibly because grafting may only have occurred on the top surface of the ePTFE. The penetration of the FTIR analysis was at the micrometre scale, whereas grafting may have occurred only on the very top surface of the ePTFE. In addition, the grafting obtained in this study was much lower compared to a previous study reported by Hidzir et al. [8].

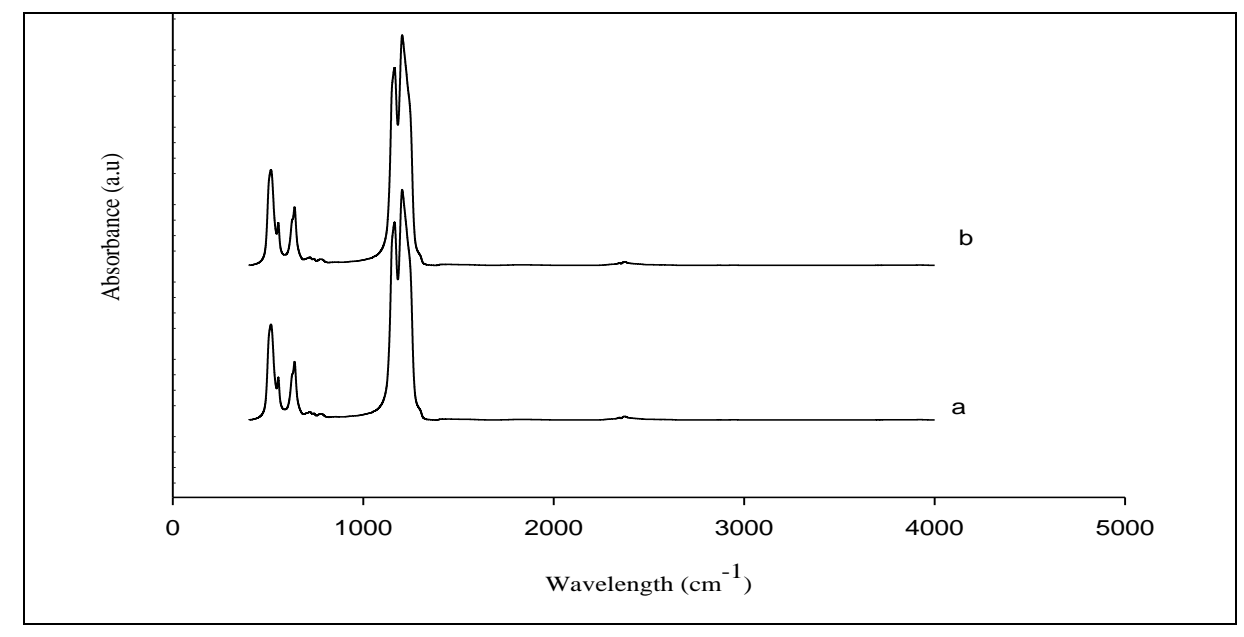

Figure 2. FTIR spectrum sample (a) untreated sample ePTFE and (b) AA(20)15

\section{Morphology and chemical composition analysis of ePTFE and grafted ePTFE}

Figure 3(a) shows the morphology of the ePTFE, which consists of islands and fibrils. The morphology of the grafted samples was observed to change, with less pores seen after grafting (Figure 3(b-f)). The change of this morphology was because the AA has been covered on the top surface of the ePTFE, resulting in less pores observed. 

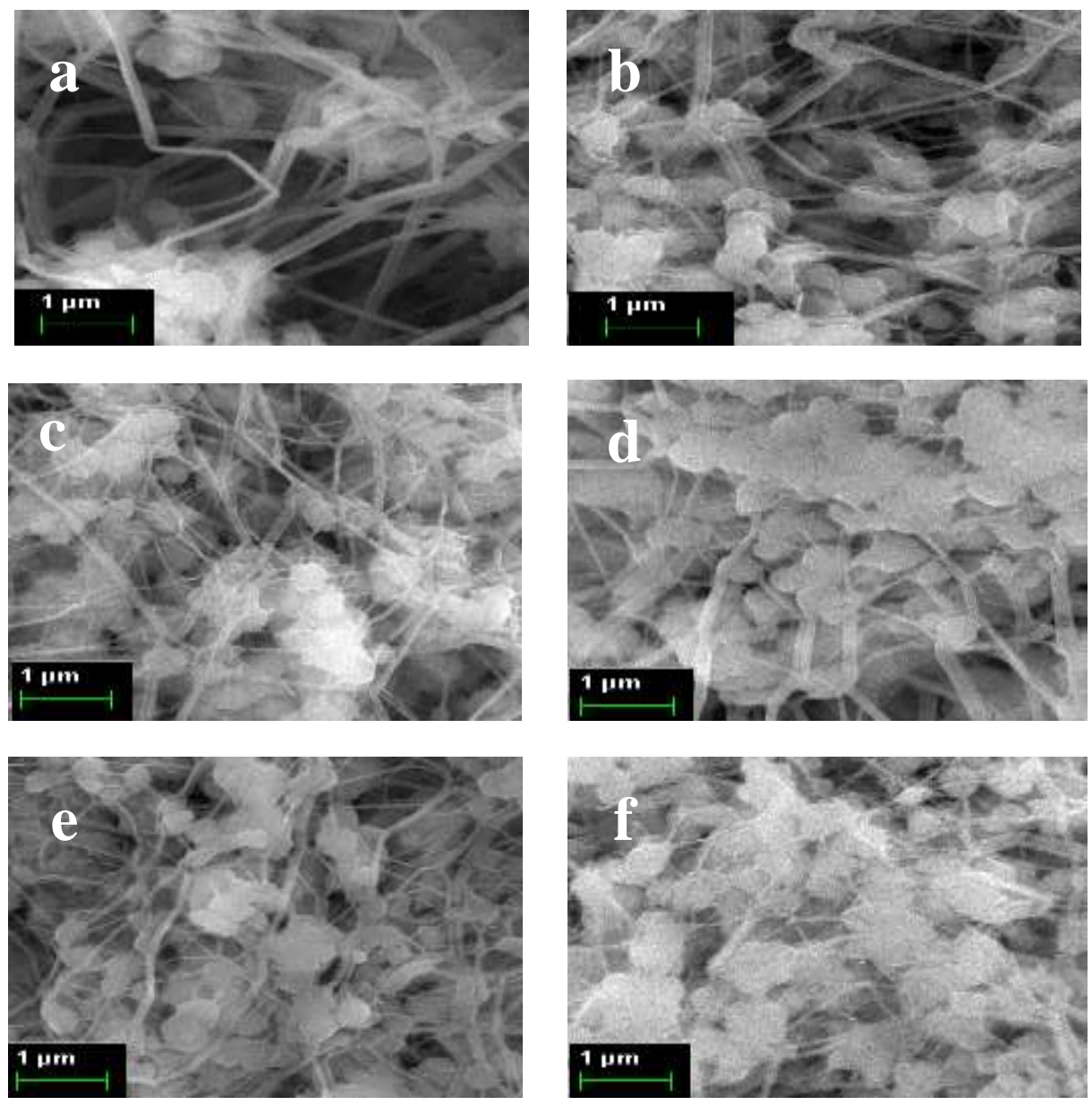

Figure 3. FESEM/EDX analysis of (a) untreated ePTFE, (b) AA(2)10, (c) AA(10)10, (d) AA(20)10, (e) AA(10)15 and (f) AA(20)15. Magnification for all images is 5000x

In addition, more island morphology was observed compared to fibril morphology in samples that have been grafted with higher doses and monomer concentrations (i.e., sample AA(20)15). Morphological changes are possibly due to the increased grafting percentage of AA. High doses and monomer concentrations allows more grafting of the AA onto the ePTFE surface. It was reported that the polymerisation could take place on the membrane surface and inside the pores, particularly when a high grafting degree was obtained $[15,16]$.

The EDX analysis shows the untreated ePTFE, which only consists of carbon and fluorine (Table 2). Oxygen was observed for the grafted sample (sample (AA(20)15) (Table 2)). In addition, the percentage of carbon weight for the grafted sample was observed to decrease from $22.66 \%$ (unticated ePTFE) to $18.92 \%$ (Table 2). Similarly, the ratio of carbon to fluorine (C:F) was observed to decrease for the grafted sample (sample AA(20)15) compared to the untreated ePTFE (Table 2). Through previous studies, the ratio of carbon to fluorine (C:F) was reported to decrease, but the ratio of carbon to oxygen $(\mathrm{C}: \mathrm{O})$ was increased due to the defluorination and oxidation occurring on the surface and shows the formation of hydrophilic ions on the surface [17]. 
Table 2. Comparison of elements on untreated ePTFE and sample AA(20)15 from the EDX analysis

\begin{tabular}{llcc}
\hline Sample & Element & Weight $(\%)$ & Atom $(\%)$ \\
\hline \multirow{3}{*}{ ePTFE } & C & 22.66 & 31.67 \\
& F & 77.34 & 68.33 \\
& Total & 100.00 & 100.00 \\
\hline \multirow{4}{*}{ AA(20)15 } & C & 18.92 & 26.92 \\
& O & 0.74 & 0.79 \\
& F & 80.34 & 72.29 \\
& Total & 100.00 & 100.00 \\
\hline
\end{tabular}

\section{Conclusion}

This study represents the first thorough investigation into gamma irradiation-induced grafting of AA onto ePTFE. It was found that grafting AA increased with higher doses and monomer concentrations. From FESEM/EDX analysis, it was found that grafting was successfully achieved. This grafting has resulted in the change of high hydrophobicity of ePTFE to less hydrophobicity with high water uptake for the grafted sample. This resulted in the desired characteristics of this ePTFE to be used in biomaterial applications, such as for bone tissue, bypass grafts, and artificial valves. However, further analysis, such as in-vitro mineralisation and protein adsorption studies, could provide more details on the biocompatibility of this polymer for such applications.

\section{Acknowledgement}

The authors wish to thank School of Applied Physics, UKM especially Nuclear Science Programme, GGPM-2015038, DLP-2014-011, and FRGS/1/2014/SG06/UKM/02/3 for the funds. The authors acknowledge the facilities and the technical assistance of the Centre of Research and Instrumental, UKM for FESEM/EDX analysis and School of Chemistry and Food Technology, UKM for assistance with FTIR analysis.

\section{References}

1. Cassady, A. I., Hidzir, N. M. and Grøndahl, L. (2014). Enhancing expanded poly(tetrafluoroethylene) (ePTFE) for biomaterials applications. Journal of Applied Polymer Science, 131 (15): 40533 - 40547.

2. Kannan, R. Y., Salacinski, H. J., Butler, P. E., Hamilton, G. and Seifalian, A. M. (2005). Current status of prosthetic bypass grafts: A review. Journal of Biomedical Materials Research Part B. Applied Biomaterials, 74(1): 570 - 581 .

3. Wentrup-Byrne, E., Grøndahl, L. and Suzuki, S. (2005). Methacryloxyethyl phosphate-grafted expanded polytetrafluoroethylene membranes for biomedical applications. Polymer International, 54 (12): 1581 -1588.

4. Wu, T. H., Chen, K. S., Chen, S. C., Yeh, Y. C. and Shen, L. H. (2008). The Biomedical material of functional ePTFE hydrogels by the cold plasma method and radiation technique. Advanced Materials Research, 47-50: $1427-1429$.

5. Rosli, N. A., Ahmad, I., Abdullah, I. and Anuar, F. H. (2014). Graft copolymerization of methyl methacrylate onto agave cellulose. Malaysian Journal of Analytical Science, 18(2): 398 - 404.

6. Naemuddin, N. H., Suradi, S. S., Jamaluddin, J. and Adrus, N. (2015). Photografting of polyacrylamide hydrogel coating onto various polyethylene terephthalate textiles. Malaysian Journal of Analytical Sciences, 19(1): $163-172$.

7. Hidzir, N. M., Lee, Q., Hill, D. J. T., Rasoul, F. and Grondahl, L. (2014). Grafting of acrylic acid-co-itaconic acid onto ePTFE and characterization of water uptake by the graft copolymers. Journal of Applied Polymer Science, 132(7):41482 - 41494.

8. Hidzir, N. M., Hill, D. J. T., Martin, D. and Grøndahl, L. (2012). Radiation-induced grafting of acrylic acid onto expanded poly(tetrafluoroethylene) membranes, Polymer, 53(26): 6063 - 6071. 
9. Hidzir, N. M., Hill, D. J. T., Taran, E., Martin, D. and Grøndahl, L. (2013). Argon plasma treatment-induced grafting of acrylic acid onto expanded poly(tetrafluoroethylene) membranes. Polymer, 54(24): 6536 - 6546.

10. Dargaville, T. R., George, G. A., Hill, D. J. T. and Whittaker, A. K. (2003). High energy radiation grafting of fluoropolymers. Progress in Polymer Science, 28(9): 1355 - 1376.

11. Chandler-Temple, A., Wentrup-Byrne, E., Whittaker, A. K. and Grøndahl, L. (2010). Graft copolymerization of methoxyacrylethyl phosphate onto expanded poly(tetrafluoroethylene) facial membranes. Journal of Applied Polymer Science, 117(6): 3331 - 3339.

12. Yu, L., He, Y., Bin, L. and Yue'e, F. (2003). Study of radiation-induced graft copolymerization of butyl acrylate onto chitosan in acetic acid aqueous solution. Journal of Applied Polymer Science, 90(10): 2855 2860.

13. Nasef, M. M. (2001). Effect of solvents on radiation-induced grafting of styrene onto fluorinated polymer films. Polymer International, 50 (3): 338 - 346.

14. Chandler-Temple, A. F., Wentrup-Byrne, E., Griesser, H. J., Jasieniak, M., Whittaker, A. K. and Grøndahl, L. (2010). Comprehensive characterization of grafted expanded poly(tetrafluoroethylene) for medical applications. Langmuir, 26(19): $15409-15417$.

15. Xu, Z., Wan, L. and Huang, X. (2009). Surface engineering of polymer membranes. Zhejiang University Press, Hangzhou: pp. 82.

16. Freger, V., Gilron, J. and Belfer, S. (2002). TFC polyamide membranes modified by grafting of hydrophilic polymers: An FT-IR/AFM/TEM study. Journal of Membrane Science, 209(1): 283 - 292.

17. Pelagade, S. M., Singh, N. L., Rane, R. S., Mukherjee, S., Deshpande, U. P., Ganesan, V. and Shripathi, T. (2012). Investigation of surface free energy for PTFE polymer by bipolar argon plasma treatment. Journal of Surface Engineered Materials and Advanced Technology, 2: 132 - 136. 